УДК 791.224.1:791.632](477)(045)

ORCID: https://orcid.org/0000-0002-0774-9845

Голіченко Юрій Миколайович,

старший викладач, художній керівник курсу, аспірант кафедри кінознавства. Київський національний університет театру, кіно і телебачення ім. І. К. Карпенка-Карого, Київ

Yurii Holichenko,

Senior teacher, artistic director of the course, Postgraduate student of the Department of Cinematography. Kyiv National

I. K. Karpenko-Karyi Theatre, Cinema and Television University, Kyiv

\title{
ПРАВДА В КІНО: РЕАЛІСТИЧНІСТЬ ОБРАЗУ СУЧАСНОГО УКРАЇНСЬКОГО ІСТОРИЧНОГО КІНОГЕРОЯ
}

Анотація: Стаття присвячена одному з найважливіших аспектів сучасного кіно - реалістичності образів героїв. Якими мають бути історичні постаті, зображені українськими митцями на екрані? Чи належить їм відповідати історичній правді? За статистикою українська аудиторія втратила цікавість до вітчизняних історичних фільмів. На жаль, це було пов'язано з певною невідповідністю історичним подіям, які насправді мали місце, відсутністю відчуття часу, що його автори ілюструють у фільмі. Образи більш вигадані, ніж правдиві. Художня правда - це інструмент, що допомагає відтворити історичній світ у кіно або створити вигаданий світ для відчуття справжності. У кожної людини є багаж життєвого досвіду, який дає змогу оцінити те, що показують їй, те, наскільки правдиво відображено атмосферу, деталі, стосунки на екрані. Глядач дуже гостро відчуває брехню і після цього швидко втрачає цікавість до фільму. Запропоновані в цій статті методи зменшують час на пошук середовища певного часу, в якому міг би органічно існувати герой, і відкривають додаткові можливості.

Ключові слова: Історичне кіно, теорія драми, кінодраматургія, кіногерой, мистецтвознавство.

Постановка проблеми та актуальність дослідження. Останнім часом в українському кінопросторі дедалі частіше з'являються фільми вітчизняних режисерів, які розповідають про історичні постаті: художників, політиків, науковців. Людей, які вплинули на історію та розвиток України. У багатьох фільмах такі персонажі зображуються ідеалізовано. Автори мимоволі стають заручниками дещо ідеалізованого, канонічного образу історичних персонажів, що позбавляє можливості розповісти правду про них, як реальних людей. Зважаючи на це, українська глядацька аудиторія, за статистичними дослідженнями, втратила цікавість до вітчизняних історичних фільмів.

На жаль, це було пов'язано $з$ певною невідповідністю історичним подіям, які насправді мали місце, відсутністю відчуття часу, що його автори ілюструють у фільмах. Образи більш вигадані, ніж правдиві. Такі рішення схожі на страх авторів доторкнутися до істини, показати характер таким, який він був насправді. Чи варто глядачеві так прискіпливо сприймати правду, історичну правду, icтину, умовність, достовірність?

Аналіз досліджень і публікацій. Наукові аспекти статті базуються на аналізі деяких вітчизняних та іноземних фільмів останніх років; аналізі багаторічного світового досвіду кінематографістів (у контексті статті).

Mema cmammi полягає у дослідженні розвитку протагоніста в сучасному українському кіно, вивченні структури побудови характеру історичного персонажа в сучасному світовому кіно, враховуючи тенденції світового кінематографа. Для більш чіткого розуміння проблеми, яка виникла у глядача при перегляді українського історичного кіно.

Виклад основного матеріалу. Ми спостерігаємо нині наявну дійсність, що у різні часи 
відповідно й різнилася - досить згадати минуле століття. Якщо звернутися до літературознавчого словника-довідника - це філософська категорія, яка означає все суще, незалежне від людини, тому частіше вживається у словосполученні «об'єктивна дійсність». Але все, що оточує пересічну людину - це результат надбання багатьох попередніх поколінь. Дуже важко знайти предмет, у створенні якого не брала участь людина. («Академія» 2007).

Дійсність складалася із законів того часу, предметів, технологій, які наповнювали буденне життя та багато іншого. Якщо деякі речі під впливом часу змінюються, то інші існують століттями. Десять заповідей і є, в якомусь сенсі, - одними 3 тих непорушних правил, які пережили багато епох і за якими намагається жити розсудливе суспільство. За порушення одних загрожує тюремний термін, за порушення інших - моральний тягар: совість, сором, зневага. Так чи інакше дійсність була, $€ \mathrm{i}$, мабуть, існуватиме ще довго.

За визначенням Інгардена - це позахудожня дійсність, яка існує, незважаючи на ступінь пізнання цієї дійсності. (Інгарден, 1962).

Чи можна назвати відтворення позахудожньої дійсності на екрані головним принципом, якого слід дотримуватись авторам і режисерам під час створення фільмів? Правда в кіно-це дуже складне питання для мистецтва. Маємо чимало жанрів: сюрреалізм, експресіонізм, абстракціонізм та багато інших, де поняття правди сприймається зовсім по-іншому.

Умовність теж має велике значення в кіно. Охарактеризувати умовність у мистецтві можна як реалізацію в художній творчості здатності знакових систем виражати один і той самий зміст різними структурними засобами (Лотман, 1998).

Наприклад С. Ейзенштейн свідомо відійшов від позахудожньої дійсності, побачивши в епізоді розстрілу матросів образ гігантської розгорнутої пов'язки, накинутої на очі засуджених, образ гігантської сітки, накинутої на групу живих людей. (Художественная реальность, 1985).

У мистецтві поняття правдивості спирається більше на відповідність певних рис, які стосуються певного часу. Але подібне трактування потребує розмежування, оскільки охоплює багато жанрів. (Інгарден, 1962).

Тобто сценаристові можна досконало і не знати час чи персонажів, а застосувати жанрові особливості у роботі з історичним матеріалом, закласти пласт позахудожньої дійсності - як основи майбутнього сценарію. Мистецтво не має кордонів, але головне - правильно цим скористатись. Жанр впливає на відображення правди, канони диктують умови. Пропонуємо проаналізувати це складне поняття в мистецтві на декількох прикладах.

Спробуємо визначити один з головних конфліктів у фільмі «Тарас Шевченко. Повернення» (реж. О. Денисенко, 2019), щоб зрозуміти, чому українські кінотеатри спочатку відмовилися показувати фільм на екранах. Головним конфліктом міг стати трикутник: офіцер, дружина офіцера і Шевченко. Насправді цього конфлікту у фільмі немає. Дружина офіцера любить Шевченка і самого офіцера, подібний розвиток подій викликає розгубленість. Глядач не розуміє, що відбувається. Образ дружини офіцера руйнується. Образ офіцера також неоднозначний. Герой розуміє почуття дружини до Тараса Шевченка. Він готовий знехтувати гідністю, бути поруч з дружиною, яка любить Шевченка. Наскільки уявлення авторів відповідає моральній та історичній дійсності?

Події розвиваються під час заслання Кобзаря в Новопетрівську фортецю на півострові Мангистау. Чому він потрапив туди, хто йому друг i хто його ворог, і чому майже кожна героїня історії закохана в нього - дізнатися можна лише з історичних фактів життя Т. Шевченка, які до фільму не потрапили. (Маранчак, 2020).

Шевченко в цьому фільмі вийшов не надто схожим на живу людину, це радше симулякр Шевченка і всіх сучасних про нього уявлень. Насправді уявлень, тому що образ Кобзаря максимально ідеалізовано: патріот України, поет, художник, гуманіст, поліглот, практично святий - але живої людини, за яку хотілося б переживати, у фільмі немає (Пищиков, 2020).

У сучасному інформаційному просторі доволі часто з'являються новини, де розповідають, що сталося чергове вбивство через ревнощі. Ображені чоловіки суворо карають своїх кривдників. 3 огляду на епоху, в якій відбуваються події, офіцер, наділений владою, ображений зрадою дружини, $\epsilon$ дуже небезпечним персонажем, але не в фільмі, де панує взаємна любов.

За жанром цей фільм - історична драма, а цей жанр потребує відображення достовірності, правди, хоча б якоїсь їі частини, оскільки висвітлює реальні сторінки, за словами авторів, 3 життя Кобзаря. Але у стрічці глядачеві демонструють зовсім іншу правду та історичну реальність, яку він не сприймає.

$€$ багато думок стосовно історичної правди, історичної реальності та достовірності. Наприклад, це те, що відповідає дійсності, реаліям життя - це істина. (Мельничук, 1996). 
За Александровою Л. через те, що термін «історична правда» приховує очевидну суб' єктивність і відносну достовірність, його потрібно змінити на «життєву правду», який відповідно диференціює поняття на «історичну правду» та «історичну достовірність». (Александрова, 1987).

Шевченко зображений як божество, істота, яка випромінює тільки добро, готова на самопожертвування заради батьківщини. Художній образ відсутній, тому що немає суперечностей у персонажі, незрозуміло, чого прагне герой, як все відбувалося насправді. Глядач цього теж не відчув у фільмі.

Фільм «Зрадник» (реж. М. Гаммонд, 2017), за жанром - історична драма, військова драма. У фільмі є сцена, яка розкриває загальний потенціал стрічки. Сцена, в якій герой демонструє свій фільм перед офіцером КДБ. Дія фільму відбувається на початку 70-х років минулого століття, коли КДБ був доволі впливовою структурою в світі. Офіцери КДБ вважалися елітою чекістського руху. У правоохоронних органах працювали віддані, готові до самопожертви люди. А на екрані нам показують зовсім іншого офіцера - слабкого, нехитрого. Так уявляють собі КДБ автори того часу. Але герой не кращий: наївний, робить безглузді вчинки. Важко пояснити, чому він вирішив зняти фільм, в якому, під час наступу, червоноармійці рубали мирних жителів шаблями, грабували та гвалтували. На що розраховував режисер-герой, коли знімав такий фільм? I хто в той час дав гроші на таке кіно? Адже диктатура СРСР спостерігалася в усьому. Сувора цензура в мистецтві, про яку, напевно, герой фільму нічого не знав.

Деякі критики доволі жорстко висловлювались про історичну правду та ії інтерпретацію у фільмі. Нарікання на мову, театралізованість, а головне значна кількість історичної невідповідності, що і викликає недовіру глядача (Кокотюха, 2018).

Герой живе у світі, відокремленому від СРСР 60-70-х років. Тоді, коли СРСР був небезпекою для всього світу. Автори створили фільм «під» 70-ті роки. Хоча історія розповідає про часи, коли Параджанов уже працював на кіностудії в Києві. На той час відбулася прем'єра стрічки «Тіні забутих предків», що спричинило нові арешти.

У 1965-1968 рр. супротив владі лише наростав. Параджанов разом із відомими діячами української науки і культури, протестуючи проти масових політичних арештів в Україні, звернувся до вищих партійних і державних органів з вимогою пояснити причини переслідування української інтелігенції і виступав за відкриті судові процеси для забезпечення справедливості розгляду справ.
Через що сам і постраждав: на Параджанова сфабрикували справу і в 1973 запроторили до в'язниці (Зят'єв, 2021).

У кінотеатрах згадані вище фільми майже не переглядалися, квитки продавалися в дуже малій кількості. Може, тому, що глядач хотів побачити заявлену історичну драму, замість якої на екрані отримав авторський погляд творців на історичну постать і радянську епоху. Можна констатувати, що невідповідність жанру спричинила відмову глядача від перегляду, а не тільки позахудожня історична дійсність. Відображення правдивості стосунків між людьми також вплинули на зацікавлення.

Тенденція «ідеалізування історичних постатей» не виникла у незалежній Україні, а йде з радянських часів, ще від епохи німого кіно: «Жовтень»-реж. С. Ейзенштейн, 1927; «Ленін у жовтні»-реж. М. Ромм, 1937; «Щорс»-реж. О. Довженко, 1939; «Богдан Хмельницький» 1941-го та «Тарас Шевченко» 1951 р. - реж. І. Савченко.

Ідеалізацією «хворів» і західний кінематограф: «Британська розвідка» реж. Террі О. Морс, 1940; «Дорога на Санта-Фе» реж. Майкл Кертіц, 1940; «Буря, що несе смерть» реж. Френк Борджес, 1940 рік та інші. 3 часом ця тенденція згасла, і світовий кінематограф має ігрові фільми про М. Течер, Черчілля, Меркюрі та інші.

Розглянемо фільм українського режисера Сергія Лозниці «Донбас» (2018). Ця історія сконструйована $з$ 13-ти епізодів, які розповідають про долі різних персонажів у вирі російської агресії, відтворюючи послідовно події, що сталися на Південному Сході України. За основу сценарію режисер узяв документальні матеріали з аматорських відеоресурсів YouTube, зафільмованих на території, контрольованій самопроголошеними ДНР і ЛНР у 2014-15 роках, під час бойових дій.

Фільм демонструє неможливі історії про вигаданих людей з кумедними іменами - так нам здається на перший погляд, але якщо придивитися - бентежишся від відчуття реальності. Усі обличчя в кадрі знайомі, справляється враження, що ці люди жили завжди поруч (Сорокін, 2018).

Ідея режисера використовувати хронікальні матеріали була успішною, поміж багатьох кадрів хроніки він побачив правду без перебільшення. У складних обставинах люди намагалися вижити, утекти. Ці кадри барвисто відображають правду життя, у них немає ні краплі брехні, ні постановочних ефектів, -лише біль, жах і відчуття, що ми втратили щось важливе для себе та рідних людей.

Епізод весілля сепаратистів, свідчить про роботу з ідентифікацією часу у фільмі. Головним 
персонажем є героїня Наталії Бузько - працівниця РАГСу, яка залишилася на окупованій території. У РАГСі грають галасливе весілля. Деякі ролі виконують визнані українські коміки - Тамара Яценко, Наталія Бузько і Георгій Делієв, що натякає: «Донбас»-це сатира, вона має бути смішною. Але українська публіка, яка була на показі в залі Дебюссі, майже не сміялася (Бадьйор, 2018).

Наталія Бузько грає роль жінки, яка намагалася провести шлюбну церемонію двох сепаратистів, але в неї не виходить. Ї̈і весь час перебивають, вона намагається якось керувати людьми, та марно. Люди не звертають на це уваги, вони роблять те, що хочуть. Режисер завдяки простому сюжету розповідає про хаос, який у той час панував на Сході. Ti, хто були ніким, раптом стали усім. Весілля відображає настрій людей на окупованій території в цілому. Зненацька всі відчули, що не існує жодних правил. Вони самі - правила. Глядач розуміє

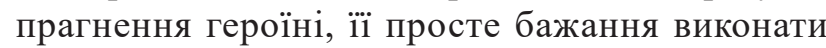
свою роботу за правилами, як це було раніше. На цій території правила діяли лише в Україні, тобто ми бачимо героїню, яка не піддається цьому фарсу навколо неї, вона розуміє, що це погано. Має бути якийсь порядок. Навіть на весільній церемонії. Порядок, який зник з повсякденного життя на окупованій території. Ми ідентифікуємо людину, це дає змогу зрозуміти, хто вона, у ширшому сенсі. І мета полягає в тому, щоб просто провести звичайну весільну церемонію. У фільмі багато подібних сцен, режисер уміло оперує атмосферою та достовірністю історичного часу.

Історична правда - це, насамперед, відображення провідних закономірностей і тенденцій суспільного розвитку, розкриття вирішальної ролі народних мас в історичному процесі (Сиротюк, 1971).

Інший фільм режисера С. Лозниці документальний, про велику трагедію Другої світової війни - «Бабин Яр» (2021), сколихнув світове кіносуспільство. Багато фільмів виходило у світовий прокат, що зображали події київської трагедії. Але жоден, як документальний, так і ігровий, не вражав своєю реалістичністю. Велика удача режисера - використаний хронікальний матеріал. Кадри, які раніше не використовувалися в медіапросторі, змонтовані, тоновані, уповільнені та озвучені таким чином, ніби глядач спостерігає за подіями, які відбулися не так давно.

Незважаючи на те, що фільм документальний, відчувається бажання режисера наблизити викладення матеріалу до ігрової інтерпретації, а не просто демонстрації хронікального матеріалу. Цей під- хід вдало працює на сприйняття глядачем фільму та відчуття правди й достовірності. Прагнення режисера через подібне викладення матеріалу швидше і якісніше передати історичну дійсність, викликає повагу (Глонь, 2021).

А ось як досягнуто відчуття історичної правди у фільмі «Брати Сістерс» (реж. Жак Одіар, 2018). Дикий Захід. Історія двох братів Чарлі і Елі-мисливців за головами, які працювали на Командора. Суворе життя Америки кінця XVIII століття лякає жорстокістю, брати - іï яскраві представники. Чутки про Чарлі та Елі линуть далеко попереду них. Стрічка доволі динамічна, в дусі вестернів, але автори потурбувались про деталі, які розкривають епоху з іншого боку.

Наприклад, сцена в магазині торговця. Елі вперше побачив зубні щітки, він не знав, що з цим приладдям робити. Власник магазину пояснив, але Елі все одно не зрозумів. Попри це, придбав щітку і сховав, доки не побачив, як містер Джон Морріс зранку чистить зуби. Спробував сам і був здивований ефектом. Проста деталь, але вона розкриває в епосі Дикого Заходу багато чого. Автори знайшли хорошу історичну деталь, що стосується зовнішнього вигляду. Елі, заволодівши нею, почав змінюватися.

Костюм також допомагає сценаристові відтворити час, в якому відбувається дія. Наголосити атмосферу різних епох. Багато режисерів ставляться до цього дуже відповідально, особливо режисери радянського періоду. С. Параджанову не подобалося брехати глядачеві в дрібницях. Для нього було важливо, щоб костюм, предмети, інтер'єри, 3 якими він працював, були справжніми, відповідали часу. Тільки так можна переконливо розповісти історію глядачеві. Це не завжди було можливо в кар'єрі Сергія Параджанова, але загартований в дитинстві талант великого митця, знайшов вихід у цій ситуації.

У дитинстві батько маленького Сергія працював антикваром і вчив сина оцінювати стародавні речі, коштовні прикраси лише за зовнішнім виглядом та походженням. Надалі митець використовував це вміння, особливо це помітно у пізніх роботах автора. Костюми, створені для фільмів Параджанова, не залишили байдужими кутюр'є всього світу. Параджанов вважався «своїм» у світі моди (Самусенко, 2021).

Якщо у фільмі про XVIII століття глядач може не побачити невідповідність часу, пов'язаного з костюмами, інтер'єром, мовою, то у стрічці, яка розповідає про події більш пізнього періоду: Другу світову війну, Чорнобильську трагедію або розпад 
СРСР, точно відчує неправду. Іноді у сучасному українському фільмі про 80-ті рокі минулого століття, деталі костюмів не відповідають часу; інша мова - більш просунута, сучасна; сучасніші інтер'єри.

Також існує визначення - художня прав$\partial a$ в кіно. За літературознавчим словникомдовідником художня правда - основне поняття теорії реалізму, яке характеризує ізоморфність створеного митцями світу 3 реальною дійсністю (відтворення життя у формах життя). Але не є їі копією. Відтворені чи витворені уявою письменника предмети, людські постаті, події є узагальненими, типовими образами, але залишаються правдивими чи правдоподібними. («Академія», 2007).

Мистецтво створює уявну істоту - художню реальність, творчість, нову форму буття (Каган, 1997). Переконливо змальований світ, який не потребує бути схожим на дійсність, але відображати сутність (Дудіков, 2012). Авторам треба намагатися розкрити історичний образ, зображаючи його роль в історії. Насамперед особливі вчинки, якими запам'ятався; риси, яких, може, ні в кого більше не було (Сиротюк, 1971). Художня правда - синтез історичної достовірності й художнього вимислу, за допомогою якого автор створює художній образ, оцінюючи життєві явища 3 позицій передового ідеалу сучасності (Александрова, 1987).

Сучасному сценаристові художня правда дуже часто стає в пригоді. Головна проблема полягає в складності ретельно відновити всі подробиці того часу, в якому відбувається дія. Особливо якщо події відбулися сто чи й більше років тому. Знайти загальний опис історичної ситуації реально, але всі емоції та хвилювання, що їх довелося пережити історичному героєві в реальному житті, під час прийняття важливого для себе, для країни чи континенту, piшення, - неможливо. Автори можуть лише здогадуватись, що відчував герой у реальній ситуації.

Для сценариста головне - побудувати кінодраматургію. Доволі часто тих перипетій, що їх зображують кінематографісти, у житті видатних людей не відбувалося. Або герої були не такими емоційними, відлюдькуватими, обирали для себе аскетичний спосіб життя. А для кіно потрібна дія, слід створити образ, показати проблему, взаємодію 3 іншими персонажами. Найчастіше глядач знає лише загальні відомості про людину, яка дивиться фільм. Наприклад, Володимир Хреститель, що ми знаємо про нього? І ось художня правда цілком може сприйматися глядачем як єдино істинна. Цей прийом у негативному сенсі успішно використовують деякі провладні кінематографісти північ- ного сусіда, для того, щоб змінити уявлення про справжні історичні події, замінити на зручніші для влади. Їм це вдається, частина російського глядача, на жаль, підтримує подібні фільми, вважаючи їх правдивими. Як, наприклад, фільм «Вікінг» (реж. Андрій Кравчук, 2016).

Режисер намагається за допомогою кінематографічних засобів, розповісти зовсім нову історію Київської Русі, в якій Київ - зовсім не є матір'ю городів руських, його роль маленька, майже непомітна в контексті сценарію (Явір, 2017).

Інший приклад того, як 3 художньою правдою працюють деякі закордонні режисери. Замість реального історичного героя в історії використовується узагальнений образ людини того часу, соціального стану. Прототип, який вміщує в собі багато якостей, характерних для своєї епохи, для ретельнішого відчуття правди. Найчастіше це використовується авторами для того, щоб отримати певну свободу в побудові композиції, вчинки героя не пов'язуватимуть 3 конкретною історичною постаттю.

Дія фільму «Одного разу в Голлівуді» (реж. К. Тарантіно, 2019), відбувається наприкінці 60-х років минулого століття. Масштабна картина про важливу епоху в Голлівуді. Завдання дуже складне для режисера: відтворити світ, суспільство тих часів. Завдання, яке в українському кіно, на жаль, зараз важко втілити через певні проблеми пов'язані 3 фінансуванням, а також 3 побудовою драматургії. Режисер цього фільму приділяє велику увагу образу героя, щоб глядач, передусім, побачив людину $з$ подібними проблемами. Не має значення, що Рік - телезірка, він людина, як і всі інші, він керується тими ж інстинктами. Природа не придумала нічого нового для Ріка. Він бачить і відчуває навколишній світ таким, який він $€$ насправді. Незважаючи на свій статус, він відчуває себе маленькою істоткою у величезному світі. В експозиції глядач бачить Ріка Далтона, як упевнену в собі людину. Він насолоджується інтерв'ю і насолоджується життям разом зі своїм другом і дублером Кліффом Бутом. Глядач бачить звичний для себе образ - телезірок. Люди ідентифікують життя телезірок з нескінченним святом. Зніматися в кіно просто: стоїте перед камерою і говорите текст. Режисер проілюстрував цей міф, як експозицію і вже в першій поворотній події почав руйнувати цей світ.

Цей фільм спрямований на тих, хто так само, як і Тарантіно, любить той час і все, що в ньому відбувалося. Режисер щиро ділиться тим, що так цінує і не хоче зраджувати свого глядача (Керніцький, 2019). 
Усі перипетії відбуваються на тлі атмосферних декорацій, які заглиблюють глядача в епоху середини 1960-х. Режисер навмисно зробив персонаж вигаданим, втіливши в одній особі зріз покоління акторів того часу, епоху в Голлівуді та долю, яка чекала на всіх, хто грав протагоністів, що досягали пенсійного віку. Автор поєднує образ телезірки і звичайної людини. Глядач починає поступово відкривати правду про Ріка, розуміючи справжню істину про зірок того часу, хоч якою б вона була. Автор не соромиться показувати героїв 3 досить неприємного ракурсу: історичні герої (наприклад. молодий ще тоді режисер Роман Поланський) звичайні люди. 3 подібними проблемами, як і у частини людства. Рік - зірка, але в нього проблеми 3 алкоголем. Через п'яну аварію в Ріка відібрали ліцензію, тепер його водій - Кліфф. Рік не вважає це проблемою і продовжує жити так, як раніше. Алкоголь руйнує кар'єри, сім'ї, і Рік демонструє це у фільмі, показуючи інший бік популярності. Звичайно, щоб не наразитися на шквал критики, автори вимушені створювати прототип, хоча б для того, щоб не образити пам'ять конкретного митця.

У фільмі також наявні й інші реальні історичні постаті, такі, як Брюс Лі, наприклад. Він зображений доволі пихатим та задерикуватим, через що відбувається бійка з дублером Ріка. Чи був насправді такий випадок, довести складно, але режисер використовує цю сцену в історії для того, щоб додати гостроти. Критики зауважили на цьому, але через те, що персонаж не головний, а епізодичний, особливих нарікань не було і невдовзі про це взагалі забули.

Фільм «Одного разу в Голлівуді» наповнений атмосферою шістдесятих років минулого століття в кожній сцені, у кожному епізоді. Зрозуміло, що режисерові дуже подобається час, який він показує у фільмі. Кожна деталь відіграє певну роль, щоб атмосфера епохи відчувалася гостріше: костюми, музика, новини з радіостанцій, діалоги, афіші, кінотеатри, літаки і т.п..

Важливим аспектом художньої правди в кіно $\epsilon$ не лише атмосфера часу, пізнаванність та деталі-стосунки між персонажами також відіграють велику роль у створенні вигаданого, неіснуючого світу, не схожого на відомий кожній людини, як і в історичній драмі. Незважаючи на візуальне оформлення світу, стосунки між людьми лишаються впізнаваними, нагадуючи реальний світ, це допомагає глядачеві глибше відчути правду. Як у сучасному фільмі $з$ вигаданим всесвітом «Вартові галактики 2» (реж. Джеймс Ганн, 2017). Головний герой розшукує свого батька. Зустріч з ним важ- лива для протагоніста, вона не дає йому спокою. Ця обставина підказує глядачеві, незважаючи на всю фантастичність героїв: правда щодо стосунків батьків і дітей схожа на стосунки звичайного глядача, і він відчуває справжність того, що демонструють на екрані.

Батьком головного героя виявляється жива планета, але перед сином він з'являється в образі звичайної людини. Фантастичний світ потребує інтерпретації зрозумілій кожному глядачу (Стрельбицька, 2017).

Як глядач сприймає вигаданого персонажа Артура в неіснуючому місті Готтем у фільмі «Джокер» (реж. Тодда Філліпса, 2019)? Готтем вигадане місто, але воно ще не досягло того фантастичного рівня та сюрреалістичного вигляду, зображеного в попередніх фільмах. Автори показують знайомий нам світ, з впізнаваними людьми, інфраструктуру міста, соціальні служби. Проблеми, пов'язані з фінансуванням різних структур. Усе, з чим ми стикаємося в повсякденному житті. Автори обирають для реалізації сучасне американське місто, воно більш знайоме глядачеві. Відчуття справжності допомагає зрозуміти глибше головного героя. Порівняти себе з ним і вирішити, наскільки чесно автори розповідають у фільмі про почуття героя, чи є почуття доречним в обраній ситуації, визначити рівень правди. Відносини між людьми, які грунтуються на зрозумілих нормах, чиних у сучасному суспільстві. Наприклад, Артур любить свою маму, не соромиться про це говорити. Для нього вона - єдина, дорога людина. I це зрозуміло майже кожному глядачеві, переважній частині. Автори використовують подібний посил, як і в фільмі «Вартові галактики 2». Глядач і в цьому разі не відчуває себе обманутим.

Висновки. Правда в кіно - це дуже складне питання для кіномистецтва, особливо зараз, коли 3'являються нові жанри, нові кіносвіти. Сценаристові дуже важко визначитися - може, правда взагалі непотрібна? Але глядач вважає інакше: при перегляді історичної драми він хоче бачити історичну драму.

Ситуація з українським кіно нині не дуже оптимістична. Витрачено мільйони державних грошей на історичне кіно, яке не хоче дивитися глядач. Головна проблема полягає в українському історичному протагоністі, який є справжнім українцем, патріотом, в ньому немає нічого негативного і не може бути. А глядач бажає побачити на екрані в історичних постатях людські якості: як вони заздрили; намагалися вижити; знайти своє місце в суспільстві; їх зраджували; іноді вони 
зраджували і не завжди були такими, як про них розповідають історики. І це цікаво. Сподівання, що українське кіно невдовзі «перехворіє» цією тенденцією, як колись західне, дуже стійке. Глядач чітко дав зрозуміти свою позицію, дивитися неправдиве історичне кіно - бажання не має.

Правда і художня правда - інструменти, що допоможуть відтворити історичній світ у кіно або створити вигаданий світ. У кожної людини є багаж життєвого досвіду, який дає змогу оцінити те, що показують йому, - наскільки правдиво відображено атмосферу, деталі, стосунки на екрані. Глядач дуже гостро відчуває брехню і після цього швидко втрачає цікавість до фільму. Запропоновані вище методи зменшують час на пошук середовища, в якому міг би існувати герой, і відкривають додаткові можливості.

\section{Джерела та література}

Александрова, Л. П. (1987). Советский исторический роман (типология и поэтика). Київ: Вища школа. Изд-во при Киевском гос. ун-те. №1-142с, №2-142 с.

Бадьйор,Д.(2018, 10травня).«Канны-2018:фантастишДонбасс», LB.ua. URL:// https://rus.lb.ua/culture/2018/05/10/397278_ kanni2018_fantastish_donbass.html

Глонь, В. (2021, 20 липня). Стаття Касьянової Д.: «,Бабий Яр. Контекст“" вызовет адский ... в Украине», birdinflight. com. URL: //https://birdinflight.com/ru/vdohnovenie/ critika/20210720-babi-yar-context.html

Дудніков, М.О. (2012). Вимисел та домисел (до проблеми історичної та художньої правди). Запоріжжя: Вісник Запорізького національного університету. Філологічні науки, $82 \mathrm{c}$.

Зятьєв С. (2021, 9 січня). «Такі, як він, завжди мутять воду...», АРМІЯ INFORM. URL: /https://armyinform.com. ua/2021/01/taki-yak-vin-zavzhdy-mutyat- vodu/

Інгарден, Р. (1962). Исследование по эстетике. Москва: Издво Иностранной литературы. №1-97 с., №2-95 с.

Каган, М.С. (1997). Эстетика как философская наука. Санкт-Петербург: ТОО ТК Петрополис. 266 с.

Керніцький А. (2019, 24 серпня). «Одного разу в Голлівуді»: туга за епохою 60-х. TCH. URL: /https://tsn.ua/blogi/ themes/culture/odnogo-razu-v-gollivudi-1399887.html

Кокотюха, А. (2018, 27 квітня). «Зрадник» і контекст українського кіно. Детектор Медіa. URL: //https://detector. media/kritika/article/137018/2018-04-27-zradnyk-ikontekst-ukrainskogo-kino/

Літературознавчий словник-довідник. Друге видання виправлене, доповнене. Київ: Видавничий центр «Академія». 2007. №1-201с., №2-719 c.

Лотман, Ю.М. (1998). Об искусстве. Санкт-Петербург: Искусство-СПБ. 375 с.

Маранчак, М. (2020, 8 жовтня). В ожидании свободы: рецензия на фильм «Тарас. Возвращение». НОВЕ УКРАЇНCDKE KIHO. URL://https://www.cinema.in.ua/ru/recenziyataras-vozvrashchenie/

Мельничук, Б. І. (1966). Випробування істиною: Проблема історичної та художньої правди в украӥнській історико біографічній літературі (Від початків до сьогодення) Київ: Академія. 14 с.

Пищиков К. (2020, 20 жовтня). Симулякр Шевченка у фільмі «Tарас. Повернення». LB.ua. URL: //https://rus.lb.ua/blog/ young_filmcritics/468757_simulyakr_shevchenka_filmi taras.html

Самусенко, Ю. (2021, 16 січня). Питання віддчуттів та образності. Як дивитися фільми Сергія Параджанова. Суспільне Медіа. URL: //https://suspilne.media/95586pitanna-viddcuttiv-ta-obraznosti-ak-divitisa-filmi-sergiaparadzanova/

Сиротюк, М. (1971). Український радянський історичний роман: [монографія]. Київ: Наукова думка, 1971. №1-45 с., №2-44 c.

Сорокін, М. (2018, 19 серпня). Летопись разрухи: рецензия на фильм «Донбасс» Сергея Лозницы. Flashforward Magazine. URL: //https://flashforward.media/donbasssergei-loznitsa-review/

Стрельбицька, О. (2017, 5 травня). Рецензія на фільм «Вартові Галактики 2». Повернення безбашенної супергеройської сімейки. Kinofilms.ua. URL: //https://www.kinofilms. ua/ukr/news/11748/

Художественная реальность (1985). Сб. науч. тр. Свердловск: УрГУ. $37 \mathrm{c.}$

Явір, В. (2017, 7 квітня): «Вікінг». Рецензія на фільм про князя-хрестителя. СПІЛЬНЕ COMMONS. URL: /https:// commons.com.ua/uk/viking- recenziya-na-film/

\section{References}

Alexandrova, L.P. (1987). Soviet historical novel (typology and poetics) Kyiv: Higher school. Publishing house at the Kiev State. Univ. №1-142p., №2-142 p.

Badior, D. (2018, May 10). «Cannes 2018: fantastic Donbass», LB.ua. URL: //https://rus.lb.ua/culture/2018/05/10/397278_ kanni2018_fantastish_donbass.html

Glon, V. (2021, July 20). Article by Kasyanova D.: «"Babyn Yar. Context»... will cause a hellish...in Ukraine», birdinflight. com. URL: //https://birdinflight.com/ru/vdohnovenie/ critika/20210720-babi-yar-context.html

Dudnikov, M.O. (2012). Fiction and conjecture (to the problem of historical and artistic truth). Zaporozhya: Bulletin of Zaporozhya National University. Philological Sciences. 82 p.

Zyatiev, S. (2021, January 9). «People like him always muddy the water...», ARMY INFORM. URL: //https://armyinform. com.ua/2021/01/taki-yak-vin-zavzhdy-mutyat-vodu /

Ingarden, R. (1962). Research of aesthetics. Moscow: Publishing House of Foreign Literature. №1-97 p., №2-95 p.

Kagan, M.S. (1997). Aesthetics as a philosophical science. Saint Petersburg: TOO TK Petropolis. $266 \mathrm{p}$.

Kernitsky, A. (2019, August 24). «Once in Hollywood»: longing for the era of the 60's. TSN. URL: //https://tsn.ua/blogi/ themes/culture/odnogo-razu-v-gollivudi-1399887.html

Kokotiukha, A. (2018, April 27). «Traitor» and the context of Ukrainian cinema. Media Detector. URL: //https:// detector.media/kritika/article/137018/2018-04-27zradnyk-i-kontekst-ukrainskogo-kino/Literary dictionaryreference book (2007). The second edition is corrected and supplemented. Kyiv: Publishing Center «Academy». №1201p., №2-719 p.

Lotman ,Yu.M. (1998). About art. Saint Petersburg: TOO TK Petropolis. 375 p.

Maranchak, M. (2020, October 8). Waiting for freedom: a review of the film «Taras. Return» NEW UKRAINIAN CINEMA. URL: // https://www.cinema.in.ua/ru/recenziya-taras-vozvrashchenie/

Melnychuk, B.I. (1996). Test of truth: The problem of historical and artistic truth in the Ukrainian historical and biographical literature (From the beginning to the present). Kyiv: Academy. 14 p.

Pyshchykov, K. (2020, October 20). Shevchenko's simulacrum in the film «Taras. Return». LB.ua. URL: //https://rus.lb.ua/ blog/young_filmcritics/468757_simulyakr_s hevchenka_ filmi_taras.html 
Samusenko, Y. (2021, January 16). Questions of feelings and imagery. How to watch movies by Sergei Parajanov. Public Media. URL: //https://suspilne.media/95586-pitannaviddcuttiv-ta-obraznosti-ak-divitisa-filmi-sergia-paradzanova/

Syrotiuk, M. (1971). Ukrainian Soviet historical novel: [monograph]. Kyiv: Naukova Dumka. №1-45 p., №2-44 p.

Sorokin, M. (2018, August 19). Chronicle of destruction: a review of the film «Donbass» by Sergei Loznitsa. Flashforward Magazine. URL: //https://flashforward.media/donbass-sergei-loznitsa-review/
Strelbytska, O. (2017, May 5). Review of the movie «Guardians of the Galaxy 2». The return of a crazy superhero family. Kinofilms.ua. URL: //https://www.kinofilms.ua/ukr/news/ $11748 /$

Artistic reality: Collection of scientific works (1985). Sverdlovsk: USU. 37 p.

Yavir, V. (April 7, 2017): «Viking». Review of the film about the prince-baptist. COMMONS COMMONS. URL://https:// commons.com.ua/uk/viking- recenziya-na-film /

\section{Yuriy Holichenko}

\section{The truth in cinema: the realism of the image of a modern historical film hero}

Abstracts: The article is devoted to one of the most important aspects of modern cinema-the realism of the hero's characters. What should be the historical figures depicted by the Ukrainian artists on the screen? Do they need to correspond to the historical truth? According to statistics, the Ukrainian audience has lost interest in domestic historical films. Unfortunately, this was due to a certain inconsistency with the historical events that actually took place, the lack of a sense of time, which the authors illustrate in the film. Images are more fictional than true. Artistic truth is a tool that helps to recreate the historical world in cinema, or to create a fictional world, for a sense of authenticity. Everyone has a baggage of life experience that allows them to assess what they show them, how truly reflected the atmosphere, details, relationships on the screen. The viewer is acutely aware of the lie and then quickly loses interest in the film. The methods proposed in this article reduce the time to find an environment of a certain time in which the hero could exist organically, and open up additional opportunities.

Key words: Historical cinema, Drama theory, Dramaturgy, Film hero, Art history. 